\title{
Suramin Rapidly Alters Cellular Tyrosine Phosphorylation in Prostate Cancer Cell Lines
}

\author{
Oliver Sartor, Catherine A. McLellan, Charles E. Myers, and Markus M. Borner \\ Clinical Pharmacology Branch, Division of Cancer Treatment, National Cancer Institute, Bethesda, Maryland 20892
}

\begin{abstract}
Suramin, a synthetic polysulfonated anionic compound, is known to abrogate the activity of a variety of growth factors that serve as ligands for receptor-class protein-tyrosine kinases. Based on this information, we initially hypothesized that suramin treatment would be associated with decreased tyrosine phosphorylation. Upon testing this hypothesis in prostate cancer cell lines, we found that the most conspicuous effect of suramin was to increase the tyrosine phosphorylation of several distinct proteins. Further analyses indicate that suramin-induced increases in tyrosine phosphorylation represent a generalized, but not universal, phenomenon found in cell lines derived from a variety of human tissues. These rapid and specific suramin-induced alterations represent a novel finding for a nonpolypeptide pharmaceutical agent and question the hypothesis that suramin exerts its antitumor action simply by abrogation of growth factor action. (J. Clin. Invest. 1992. 90:2166-2174.) Key words: epithelial cell lines • polyanions $\bullet$ prostate $\bullet$ suramin - tyrosine phosphorylation
\end{abstract}

\section{Introduction}

Suramin is the hexasodium salt of carbonyl bis [ 8-(3-aminobenzamido) 4-methylbenzamido]-naphthalene-4,6,8 trisulfonate (Fig. 1). A synthetic compound, suramin was originally synthesized in 1916 by Bayer AG as part of an ongoing search for antitrypanosomal chemotherapeutic agents. After demonstration of activity against trypanosomes in model systems, and the subsequent discovery of its activity against onchercerciasis, suramin has been used to treat parasite-infected patients throughout the world since the 1920 s (1).

In 1984 suramin was reported to dissociate platelet-derived growth factor (PDGF) ${ }^{1}$ from its receptor and block the binding of PDGF to cell membranes (2). The mechanism whereby suramin inhibits PDGF binding to its receptor is secondary to a direct attachment of suramin to the PDGF molecule (3). In v-sis transformed fibroblasts, where activation of the PDGF

Address reprint requests to Dr. Sartor, Clinical Pharmacology Branch, Building 10, Room 12N226, National Cancer Institute, Bethesda, MD 20892.

Received for publication 16 January 1992 and in revised form 24 July 1992.

1. Abbreviations used in this paper: FGF, fibroblast growth factor; GAP, ras GTPase activating protein; LSB, Laemmli sample buffer; NCI, National Cancer Institute; PDGF, platelet-derived growth factor; PLC- $\gamma$, phospholipase C- $\gamma$; TGF- $\alpha$, transforming growth factor; TNESV, Tris $50 \mathrm{mM}$, pH 7.6, NP-40 1\%, EDTA $2 \mathrm{mM}, \mathrm{NaCl}, 100$ $\mathrm{mM}$, and vanadate $1 \mathrm{mM}$.

The Journal of Clinical Investigation, Inc.

Volume 90, December 1992, 2166-2174 receptor is a requisite for transformation, suramin induces phenotypic reversion (4) and decreases the extent of cellular tyrosine phosphorylation (5). Subsequent studies indicate that suramin can inhibit the activity of a number of peptides known to stimulate cellular tyrosine phosphorylation including basic fibroblast growth factor (bFGF) $(6,7)$, the product of the hst/ $\mathrm{K}-f g f$ gene (8), interleukin $2(9)$, and scatter factor (also known as hepatocyte growth factor) (10).

Beginning in 1987, prompted by reports that suramin reversed a variety of growth factor-induced actions, suramin was administered in clinical trials and found to have antitumor activity (11). More recently, in both model systems (12-14) and in clinical trials $(15,16)$, suramin has been demonstrated to have antitumor activity against prostatic cancer.

Given the fact that suramin antagonizes the activity of a variety of growth factors known to increase cellular tyrosine phosphorylation (see reference 17), and given the fact that suramin has antitumor activity against cell lines derived from prostatic cancer patients $(12,13)$, we initially hypothesized that suramin treatment would decrease tyrosine phosphorylation in prostate cancer cells. Upon testing this hypothesis, we were surprised to find that the most conspicuous effect of suramin was a rapid (within seconds) and marked increase in the tyrosine phosphorylation of several cellular proteins.

\section{Methods}

Cell culture. The androgen-insensitive PC 3 and DU145 and the androgen-sensitive $\mathrm{LNCaP}$ prostate cancer cell lines were obtained from the American Type Culture Collection (ATCC). PC3M, a highly metastatic variant of PC3 cells, was obtained from Dr. J. M. Kozlowski, Northwestern Medical School, Evanston, IL. The colon cell lines HT29, COLO 205, and SW620, and the leukemia cell lines (CEM and HL60) were obtained from ATCC. The colon cell lines NCI-H630 (designated 630) and $\mathrm{NCI}-\mathrm{H} 716$ (designated 716), originally described by Dr. A. Gazdar and colleagues (18), were obtained from the laboratory of Dr. C. Allegra. The myeloma cell lines H929 and U266 were obtained from Dr. R. Nordan, National Cancer Institute (NCI). The Burkitt's lymphoma cell lines, Defauw and Wilson, were obtained from Dr. I. Magrath, NCI. The lung cancer cell lines NCI-H82, NCI$\mathrm{N} 417$, and NCI-H226, originally derived from the laboratories of Drs. D. Carney and A. Gazdar $(19,20)$, were obtained from Dr. E. Sausville, NCI. The breast cancer cell lines H5578, T47-D, MDA-231, and ZR-75 as well as the HeLa cell line were obtained from Dr. K. Cowan, NCI. The gastric cell lines TMK-1, A2521, NUGC4, MKN74, and MKN28 were obtained from Dr. T. Toko, NCI. The medulloblastoma D283Med, the neuroepithelioma cell lines CHP-100, SKNMC, and TC32, and the melanoma cell lines RPMI-7951 and HS695T were obtained from Dr. L. Whitesell, NCI. The rhabdomyosarcoma line was obtained from Dr. L. Helman, NCI. All colon, prostate, breast, gastric, myeloma, lung, leukemia, and rhabdomyosarcoma cell lines were routinely maintained in RPMI 1640 supplemented with 10-20\% FCS, 2 $\mathrm{mM}$ glutamine, $100 \mathrm{U} / \mathrm{ml}$ penicillin, and $100 \mu \mathrm{g} / \mathrm{ml}$ streptomycin. Melanoma cells were maintained in ATCC-advised media. NIH 3T3 cells were obtained from the laboratory of Dr. S. Aaronson, NCI, and cultured in DME supplemented with $10 \%$ calf serum. 
<smiles>COc1cc(C(=O)Nc2cccc(C(=O)Nc3cccc(C(=O)Nc4cc(C(=O)Nc5ccc(S(=O)(=O)O)c6c(S(=O)(=O)O[Na])cc(S(=O)(=O)O[Na])cc56)ccc4C)c3)c2)cc(S(=O)(=O)O[Na])c1</smiles>

Figure 1. Structure of sura$\min$. Note the six sulfonic acid groups which make this compound a highly charged polyanion.
Media and all media supplements (except calf serum and humanderived blood-products) were obtained from Life Technologies Inc. (Gaithersburg, MD). Calf serum was obtained from ABI, Inc. (Columbia, MD). Fresh normal human serum was donated by one of the authors. Human platelet-poor plasma was obtained from the Division of Transfusion Medicine, NIH Clinical Center.

Immunoblotting. Cells were routinely lysed on ice with a buffer containing $50 \mathrm{mM}$ Tris, pH 7.6, 1\% NP-40, 2 mM EDTA, $100 \mathrm{mM}$ $\mathrm{NaCl}$, and $1 \mathrm{mM}$ vanadate (TNESV) freshly supplemented with $1 \mathrm{mM}$ phenylmethylsulfonyl fluoride (PMSF), $20 \mu \mathrm{g} / \mathrm{ml}$ aprotinin, and 20 $\mu \mathrm{g} / \mathrm{ml}$ leupeptin. In other cases (where designated), cells were lysed with a buffer containing $1 \%$ Triton $\mathrm{X}-100,0.5 \%$ sodium deoxycholate, $100 \mathrm{mM} \mathrm{NaCl}, 42 \mathrm{mM} \mathrm{Na}_{2} \mathrm{HPO}_{4}$, and $8 \mathrm{mM} \mathrm{NaH}_{2} \mathrm{PO}_{4}$ supplemented with protease inhibitors as described above. Protease inhibitors were obtained from Boeringer-Mannheim (Indianapolis, IN), detergents from Sigma Chemical Co. (St. Louis, MO). After clearing cellular debris by centrifugation at $15,000 \mathrm{~g}$ for $20 \mathrm{~min}$ at $4^{\circ} \mathrm{C}$, protein concentrations were determined by the Bradford method using reagents supplied by Bio-Rad Laboratories (Richmond, CA). After adding Laemmli sample buffer (LSB), samples were heated to $100^{\circ} \mathrm{C}$ and $40-60 \mu \mathrm{g}$ of protein were loaded per lane on $8 \%$ SDS-PAGE gels prepared according to the method of Laemmli (21). Bethesda Research Laboratories (Gaithersburg, MD) size markers were used for determination of protein size. After transfer to nitrocellulose, filters were blotted as previously described (22).

Preparation of membrane-enriched and cytosolic cell fractions. Cells were lysed in ice-cold hypotonic lysing buffer $(20 \mathrm{mM} \mathrm{pH} 7.6$ Hepes with $1 \mathrm{mM}$ EDTA, $1 \mathrm{mM}$ vanadate, $1 \mathrm{mM}$ PMSF, $20 \mu \mathrm{g} / \mathrm{ml}$ leupeptin, and $20 \mu \mathrm{g} / \mathrm{ml}$ aprotinin ) and all subsequent steps were performed at $4^{\circ} \mathrm{C}$. Cells were scraped from the tissue culture plate, repetitively passed through a 23-gauge needle, and nuclei were pelleted for 10 minutes at $1,000 \mathrm{~g}$. The supernatant was then removed and recentrifuged at $176,000 \mathrm{~g}$ for $1 \mathrm{~h}$. The remaining supernatant (cytosolic fraction) and the TNESV extractable portion of the pellet (membrane fraction) were size-fractionated by SDS-PAGE after boiling in LSB.

Antibodies. The anti-phosphotyrosine monoclonal antibody $4 \mathrm{G10}$, the anti-human fibroblast growth factor (FGF) receptor ( $\mathrm{flg}$ ) monoclonal antibody, the anti-ras GTPase-activating protein (anti-GAP) antisera, and the monoclonal anti-phospholipase C- $\gamma$ (PLC- $\gamma)$ were obtained from Upstate Biotechnology Incorporated (Lake Placid, NY). The anti-phosphotyrosine monoclonal antibody PY20 was obtained from ICN Biomedicals Inc. (Costa Mesa, CA). The monoclonal antibodies 3B12, 2B12, 2A7, and 4F4, recognizing (respectively) p80/ $85 \mathrm{kD}, 120 \mathrm{kD}, 125 \mathrm{kD}$, and $130 \mathrm{kD}$ proteins that are tyrosine-phosphorylated in chicken embryo fibroblasts expressing activated versions of the c-src kinase were kindly provided by Dr. T. Parsons, University of Virginia (23). The monoclonal antibodies A5C9 and MT-18, recognizing the $80-\mathrm{kD}$ component of the IL- 6 receptor were provided by Dr. R. Nordan, NCI. The anti-met antisera was provided by Dr. D. Botaro, NCI.

Immunoprecipitations. Cellular lysates were prepared with TNESV supplemented with protease-inhibitors as described above. After equalization of protein between samples $(300-600 \mu \mathrm{g}$ of protein per sample), antibodies were added for $1-4 \mathrm{~h}$ at $4^{\circ} \mathrm{C}$. Rabbit antibodies were immunoprecipitated with the aid of protein A-Sepharose beads (Pharmacia, Inc., Piscataway, NJ). Mouse monoclonal antibodies were immunoprecipitated with the aid of protein A-Sepharose beads coated with affinity-purified rabbit anti-mouse antisera (Cappel Laboratories, West Chester, PA). Beads were then washed twice with lysing buffer before boiling in LSB and fractionation by SDS-PAGE.

Immune-complex kinase assays and V8 digests. Immune-complex kinase assays and proteolytic digests with V8 protease (Worthington Biochemical Corp., Freehold, NJ) were performed exactly as previously described (22).

Metabolic labeling. Metabolic labeling with $\left[{ }^{32} \mathrm{P}\right]$ orthophosphate (New England Nuclear, Boston, MA) was performed by 2-h labeling $(0.5$ $\mathrm{mCi} / \mathrm{ml}$ ) at $37^{\circ} \mathrm{C}$ in phosphate-free RPMI (Gibco, Gaithersburg, MD).

Radioimmunoassay of transforming growth factor- $\alpha(T G F-\alpha)$. Conditioned medium was collected from PC 3 cells, cleared of debris by centrifugation, and assayed for TGF- $\alpha$ with an RIA kit obtained from Biomedical Technologies, Inc. (Stoughton, MA).

Determination of suramin concentration. Suramin levels were determined by an HPLC based assay as previously described (24).

Chemicals. Suramin and pentosan polysulfate were obtained from the Division of Cancer Treatment, NCI. Heparin from beef lung was obtained from The Upjohn Co. (Kalamazoo, MI), and heparan sulfate from the Sigma Chemical Co. Protamine sulfate was obtained from Elkins-Sinn, Inc. (Cherry Hill, NJ).

\section{Results}

To determine the effects of suramin on tyrosine phosphorylation in an androgen-insensitive prostate cancer cell line, lysates derived from PC 3 cells were examined by anti-phosphotyrosine immunoblotting (see Fig. $2 A$ ). PC 3 cells express several prominent tyrosine phosphorylated proteins of $\sim 60$ and 120 $\mathrm{kD}$ as detected by the $4 \mathrm{G} 10$ monoclonal antibody. Within seconds after treatment of cells with $300 \mu \mathrm{g} / \mathrm{ml}$ suramin, a suramin concentration utilized in the clinical setting $(15,16,25)$, several new tyrosine-phosphorylated bands were readily detected in the cellular lysates and (in some cases) the p120 band became less prominent. The most conspicuous of the newly tyrosine-phosphorylated proteins had molecular masses of $\sim 75$ and $135 \mathrm{kD}$. To verify the specificity of the $4 \mathrm{G} 10$ antibody, phenylphosphate $(10 \mathrm{mM})$ was preincubated with $4 \mathrm{G} 10$ before immunoblotting. Under these conditions, no bands were detected in suramin-treated or untreated PC 3 cells (data not shown). To determine whether these bands were detected by a second and distinct anti-phosphotyrosine antibody, we immunoblotted these same lysates using monoclonal antibody PY20 (see Fig. 2 B). In untreated PC3 cells, the $120-k D$ band was readily detectable after immunoblotting with PY20. In contrast, the $60-\mathrm{kD}$ band was much less prominent in blots with PY20 as compared to 4G10. After suramin addition, the prominent tyrosine phosphorylated bands at $\sim 75$ and $135 \mathrm{kD}$ 
A

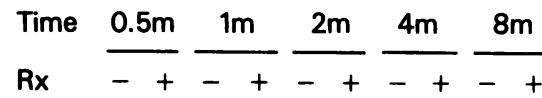

$200-$

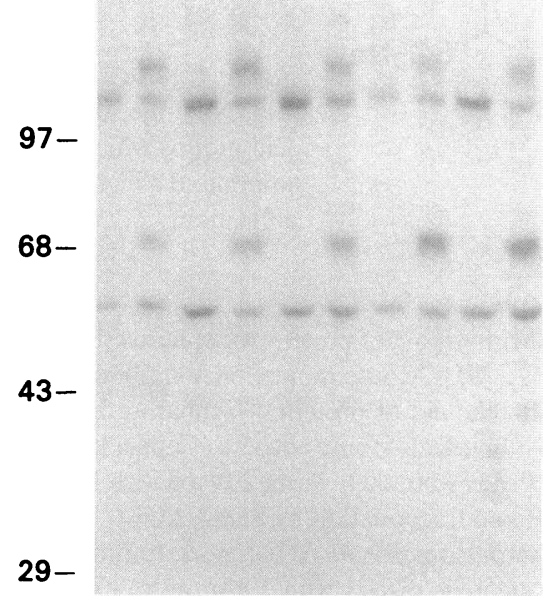

B
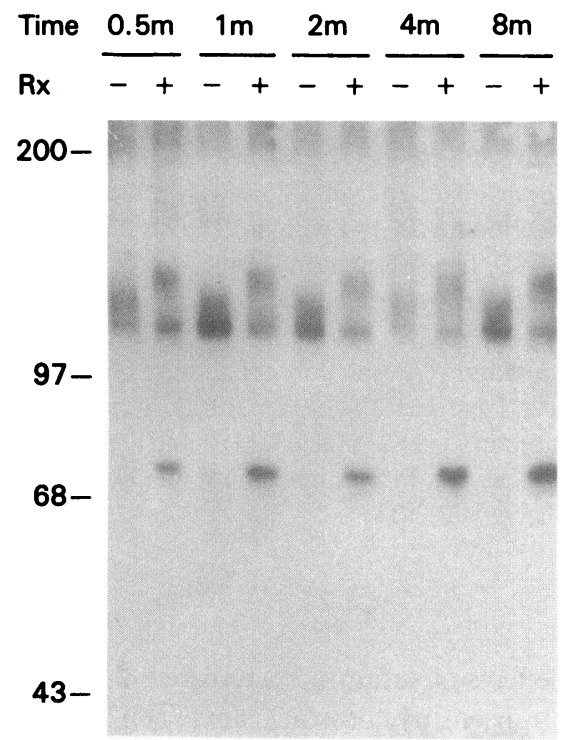

Figure 2. Suramin rapidly stimulates tyrosine phosphorylation in the prostate cancer cell line PC 3 . Suramin at a concentration of $0(-)$ or $300(+) \mu \mathrm{g} / \mathrm{ml}$ was added to the culture medium (RPMI 1640 plus $10 \%$ FCS) and cells were lysed $0.5,1,2,4$, or 8 min later. Samples were size-fractionated by SDS-PAGE, transferred to nitrocellulose, and immunoblotted with $(A)$ the anti-phosphotyrosine monoclonal antibody $4 \mathrm{G} 10$ or $(B)$ the anti-phosphotyrosine monoclonal antibody PY20. The electrophoretic mobility of molecular size markers is shown in kilodaltons.

were again readily detectable and the p120 tyrosine-phosphorylated band again became less prominent. To verify that the suramin-induced phosphorylations were not unique to the lysis conditions employed, PC 3 cells were lysed with a $1 \%$ Triton X-100/0.5\% deoxycholate based lysis buffer (see Methods) and identical results were obtained (data not shown). Thus, two well-characterized monoclonal anti-phosphotyrosine antibodies and two different lysis conditions both revealed rapid alterations in the tyrosine-phosphorylated proteins detected in the lysates derived from PC 3 cells after treatment with 300 $\mu \mathrm{g} / \mathrm{ml}$ suramin.
To ascertain whether the suramin-induced changes in tyrosine phosphorylation were indicative of broader changes in cellular phosphorylation, detergent lysates derived from metabolically labeled $\left(\left[{ }^{32} \mathrm{P}\right]\right.$ orthophosphate) PC 3 cells were examined by SDS-PAGE after suramin treatment. No differences were noted in the phosphorylated protein pattern detected in these assays, indicating that the suramin-induced changes in phosphotyrosine were not the result of global changes in phosphorylation (data not shown).

The rapidity of the changes in tyrosine phosphorylation after suramin treatment suggested that suramin interacts with a component of the culture media (such as serum) and/or a cellular component in direct contact with the extracellular environment. Because the initial experiments were performed in the presence of $10 \%$ fetal calf serum, we questioned whether or not serum would affect the suramin-induced changes in tyrosine phosphorylation. Thus, PC3 cells were washed twice with PBS and placed in RPMI without serum supplementation ("0"), RPMI plus $10 \%$ human platelet-poor plasma ("HP"), or RPMI plus $10 \%$ human serum ("HS"). Regardless of the media employed, $300 \mu \mathrm{g} / \mathrm{ml}$ of suramin induced a rapid increase in the phosphotyrosine content of the $75-$ and $135-\mathrm{kD}$ bands (Fig. 3). In other experiments, similar suramin-induced changes were noted for cells cultured in serum-free media for $72 \mathrm{~h}$ (data not shown). Thus, suramin-induced changes are not directly dependent upon interactions between suramin and serum components. Because of the rapidity of the changes, and because the entry of suramin into cells is limited by size and charge, these studies suggest that rapid suramin-induced increases in tyrosine phosphorylation are the result of an interaction between suramin and a component of the cell (such as the plasma membrane) readily accessible to the extracellular environment.

To determine if the tyrosine phosphorylated proteins detected after suramin treatment would segregate with membrane-enriched or cytosolic cell fractions, we performed immu-

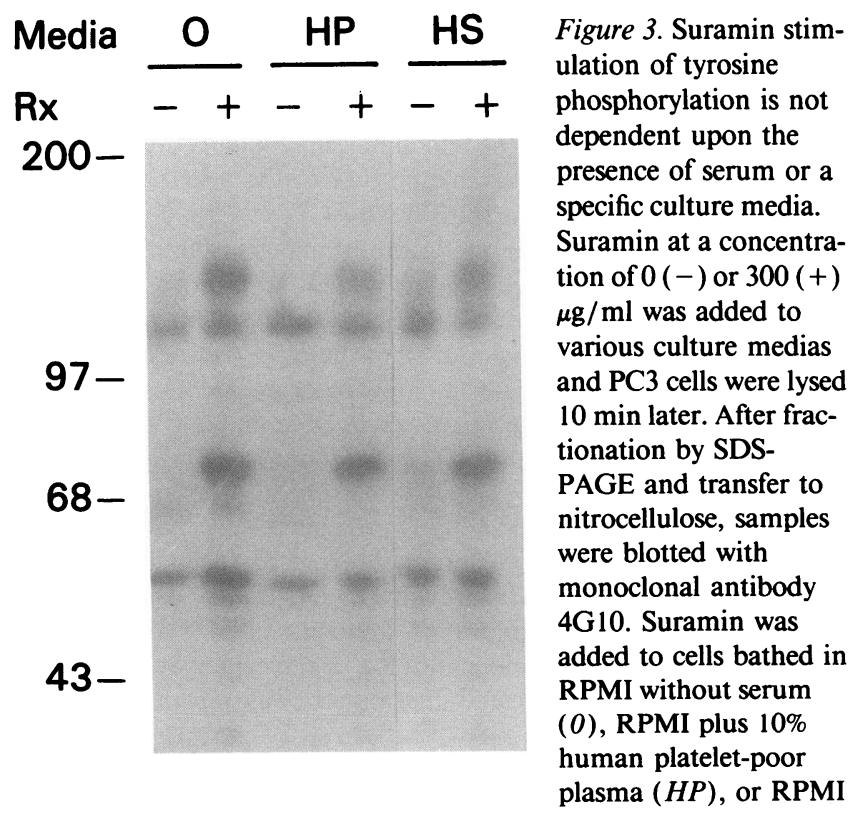

plus $10 \%$ human serum $(H S)$. The electrophoretic mobility of molecular size markers is shown in kilodaltons. 
noblots on proteins derived from each of these fractions after hypotonic lysis and differential centrifugation. From these data (not shown), it was clear that both the 75-kD band (prominent) and the 135-kD band (far less prominent) were present within the membrane fraction. Neither of these bands were present in the cytosolic fraction.

To determine the duration of the suramin response, PC3 cells were treated with $300 \mu \mathrm{g} / \mathrm{ml}$ suramin for varying periods of time. As shown in Fig. $4 \mathrm{~A}$, the tyrosine phosphorylated bands of 75 and $135 \mathrm{kD}$ were readily detected between 10 and $40 \mathrm{~min}$ after suramin addition. However, $160 \mathrm{~min}$ later, the tyrosine phosphorylation pattern was not substantially different from baseline. Also of note, the prominence of the p120 band varied in an inverse manner with that of the $\mathrm{p} 75$ and $\mathrm{p} 135$ bands. After $72 \mathrm{~h}$ of continuous exposure to 50,150 , or 300 $\mu \mathrm{g} / \mathrm{ml}$ suramin (Fig. $4 \mathrm{~B}$ ), no differences were noted in PC3 proteins as assessed by the anti-phosphotyrosine immunoblots. These data indicate that the suramin-induced changes in tyrosine phosphorylation are both rapidly induced and relatively short-lived.

The relatively short-lived drug-induced changes could be the result of alterations in the drug itself, or to a cellular "desensitization" to the drug's action. To distinguish between these possibilities, we applied suramin to PC 3 cells and measured the suramin concentration in the culture media $1 \mathrm{~min}$ and $3 \mathrm{~h}$ later and found no differences ( 279 vs. $294 \mu \mathrm{g} / \mathrm{ml}$, respectively). Furthermore, by this HPLC-based assay, we found no evidence for suramin degradation or metabolism. To determine whether the suramin-induced tyrosine phosphorylation desensitizes, the response to suramin was studied at various times after a 2-h suramin pretreatment. As shown in Fig. 5, 2 h of suramin pretreatment clearly diminishes the subsequent suramin-induced response; however, $20 \mathrm{~h}$ after pretreatment, the suramin-in- duced tyrosine phosphorylation pattern was unchanged, indicating reversibility of the desensitization process. The minor differences between the untreated lanes in this figure can be attributed to sample variation. These studies demonstrate that the relatively brief duration of the suramin-induced responses is not the result of suramin degradation, but rather the result of desensitization to the action of the drug.

To determine the dose-response curve for suramin-induced tyrosine phosphorylation in PC3 cells, cells were treated with 0 , $30,100,300,1,000$, and $3,000 \mu \mathrm{g} / \mathrm{ml}$ of suramin (Fig. $6 \mathrm{~A}$ ). From these studies it is clear that the suramin-induced alterations in tyrosine phosphorylation of the 75- and 135-kD proteins occurred at dosages of $\geq 100 \mu \mathrm{g} / \mathrm{ml}$ in the PC 3 cells. These experiments also emphasize the reciprocal relationship between tyrosine phosphorylation of the p120 and p135 bands. Because suramin is clinically used at a serum level of $\sim 300$ $\mu \mathrm{g} / \mathrm{ml}(15,16,24)$, it is clear that suramin-induced changes in tyrosine phosphorylation can occur at clinically relevant drug concentrations within this cell line. To determine whether or not these suramin-induced alterations in tyrosine phosphorylation were detectable in other prostate cancer cell lines, lysates derived from suramin treated PC3M, DU145, and LNCaP cells were immunoblotted with the $4 \mathrm{G} 10$ monoclonal antiphosphotyrosine antibody (Fig. 6, B-D). The untreated PC3M and $\mathrm{LNCaP}$ cells displayed a tyrosine phosphorylation pattern very similar to that of the PC3 cells, with prominent proteins detected at $\sim 60$ and $120 \mathrm{kD}$. In contrast, the pattern of tyrosine phosphorylated proteins in the DU145 cells was distinct. In addition to the tyrosine phosphorylated 60 - and $120-\mathrm{kD}$ proteins, prominent bands were also detected at 54 and $57 \mathrm{kD}$. After $10 \mathrm{~min}$ of suramin treatment, PC3M, DU145, and LNCaP cells responded by substantially increasing tyrosine phosphorylation of proteins in the $75-$ and $135-\mathrm{kD}$ size range.

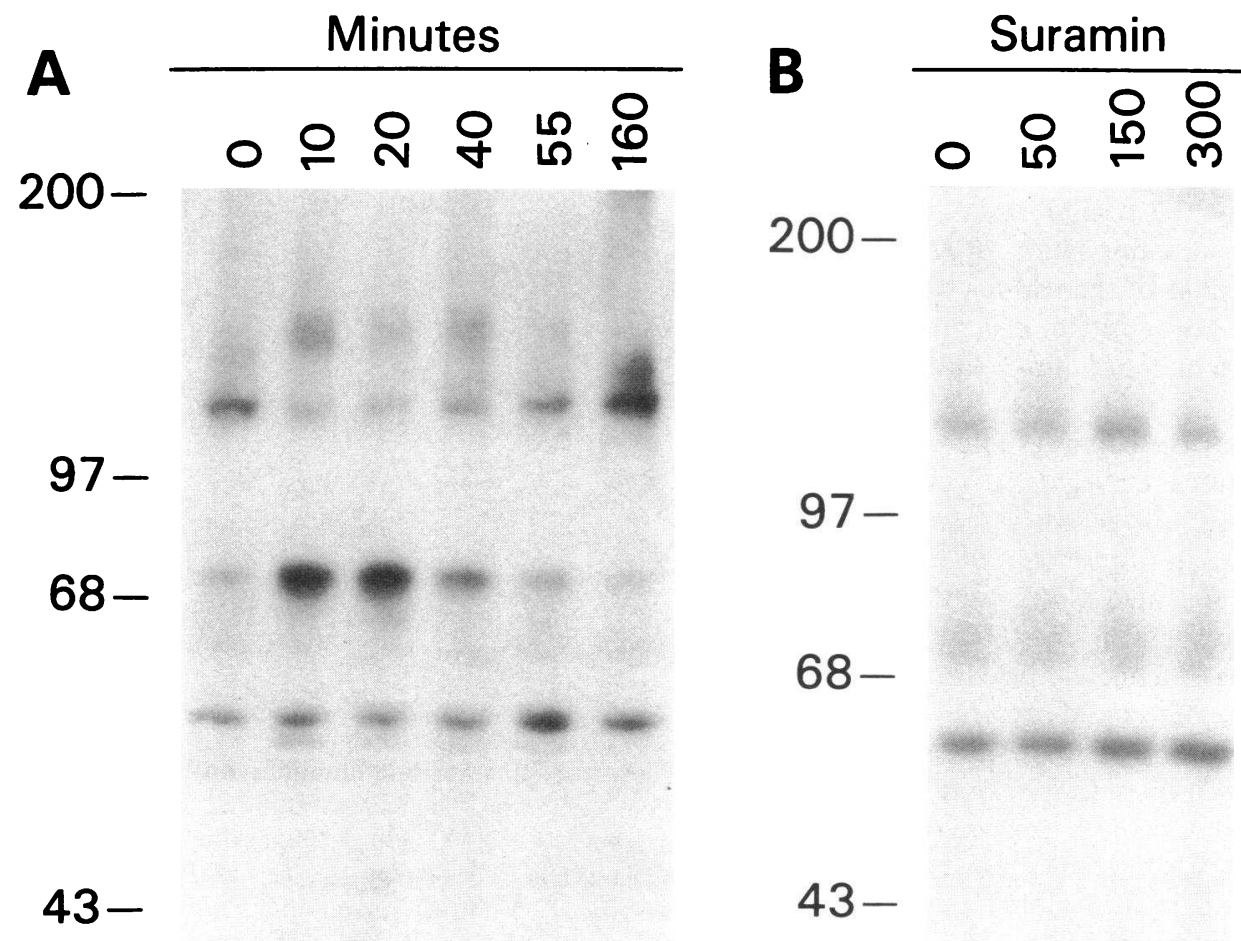

Figure 4. Time course of the suramin-induced tyrosine phosphorylation in PC 3 cells. Suramin was added to the media and cells were lysed at various time points thereafter. After SDS-PAGE and transfer to nitrocellulose, filters were immunoblotted with the monoclonal antibody $4 \mathrm{G} 10 .(A)$ Suramin $(300 \mu \mathrm{g} / \mathrm{ml})$ was added 10 , $20,40,55$, or $160 \mathrm{~min}$ before cell lysis. (B) Suramin $(0,50,150$, or $300 \mu \mathrm{g} /$ $\mathrm{ml}$ ) was added to the culture media $72 \mathrm{~h}$ before cellular lysis. The electrophoretic mobility of molecular size markers is shown in kilodaltons. 

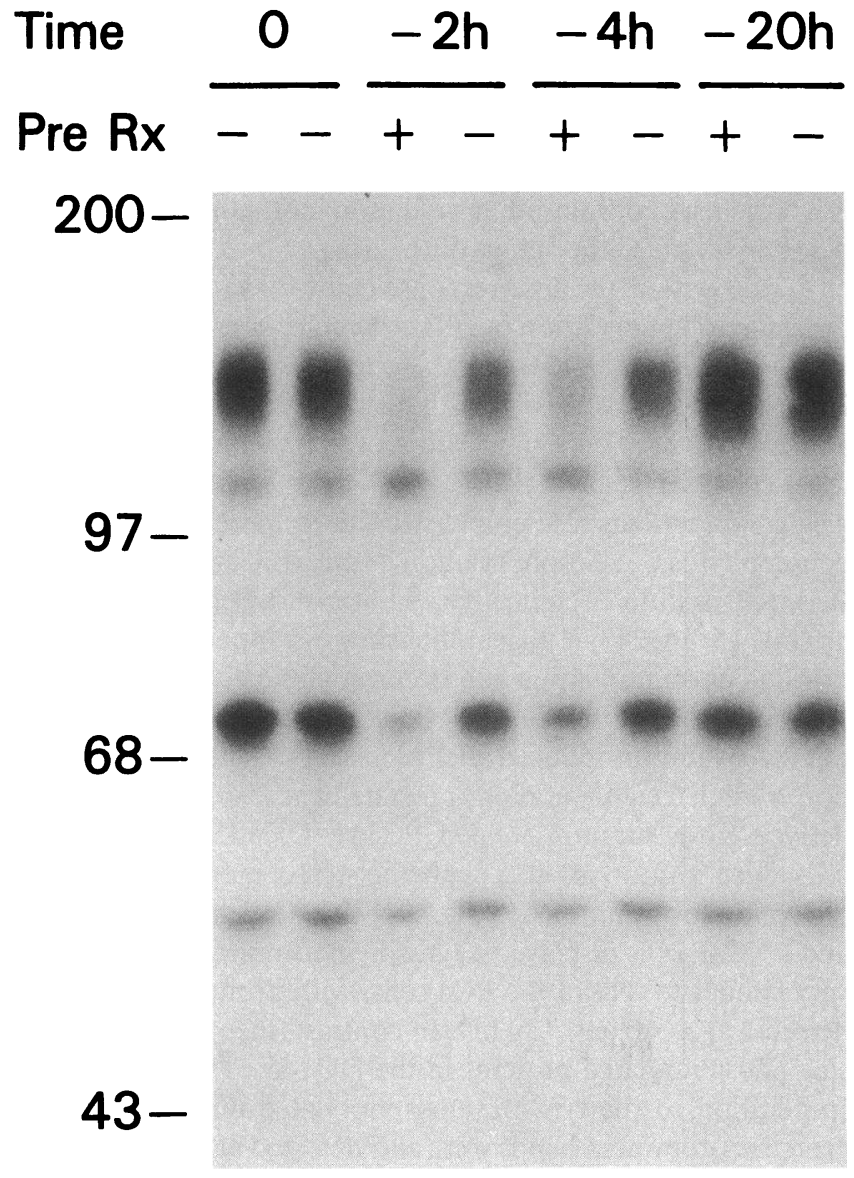

Figure 5. Desensitization, and subsequent recovery, of the suramininduced tyrosine phosphorylation. PC3 cells were pretreated with suramin at a concentration of $0(-)$ or $300(+) \mu \mathrm{g} / \mathrm{ml}$ for $2 \mathrm{~h}$. After various periods of delay $(2,4$, or $20 \mathrm{~h})$, all cells were then treated with suramin $(300 \mu \mathrm{g} / \mathrm{ml})$ and lysed $10 \mathrm{~min}$ later. Samples were size-fractionated by SDS-PAGE, transferred to nitrocellulose, and immunoblotted with the 4G10 monoclonal antibody. The electrophoretic mobility of molecular size markers is shown in kilodaltons.

The PC3M and DU145 cells, but not the LNCaP cells, responded by decreasing the tyrosine phosphorylation of the p1 20 band. Of interest, the dose response of the various cell lines was distinct, with the androgen-sensitive cell line ( $\mathrm{LNCaP}$ ) being the least sensitive to the suramin-induced changes in these assays.

We next questioned whether or not the suramin-induced alterations in tyrosine phosphorylations were relegated to cells derived from prostatic cancer. To answer this question, a variety of cell lines were treated with suramin and assayed for changes in tyrosine phosphorylation. In Table I, we summarized data from a series of suramin treated cell lines (Fig. 7, $A-D)$. From these data we conclude that cell lines derived from a number of prostate, breast, gastric, and colon cancers respond to suramin by increasing the tyrosine phosphorylation of $75-$ and $135-\mathrm{kD}$ proteins, whereas cell lines derived from a number of neuroepitheliomas, lymphomas, and leukemias do not respond in this characteristic fashion. Of interest, some of the cancer cell lines (originally derived from myelomas) did not exhibit suramin-induced alterations of $75-$ or $135-\mathrm{kD}$ bands, but did show alterations in bands of $\sim 94$ and $170 \mathrm{kD}$ (Fig. $7 \mathrm{D}$ ). In several cell lines, for instance the gastric-derived cell lines NUGC4 and MKN74 (Fig. 7 C), suramin-induced alterations were detectable within a $75-\mathrm{kD}$ protein but not within a $135-\mathrm{kD}$ protein. No cell lines had alterations in the 135-kD band alone. Several cell lines (HT29, 630, WIDR) also exhibited obvious suramin-induced tyrosine phosphorylations in proteins of $\sim 58 \mathrm{kD}$ (Fig. $7 \mathrm{~A}$ ). Suramin also induced a modest decrease in tyrosine phosphorylation of a $120-\mathrm{kD}$ band, however, these effects were limited to PC 3 (Fig. $7 C$ ) and HT29 cells (Fig. $7 A$ ). Thus, although acute suramin-induced decreases in tyrosine phosphorylation are detectable, they are relatively limited in comparison to suramin-induced increases in tyrosine phosphorylation. From these data we conclude that suramin-induced alterations in tyrosine phosphorylations are a common feature of many, but not all, cell lines. As a generalization, cells with the suramin-induced $75-$ and $135-\mathrm{kD}$ bands were derived from epithelial adenocarcinomas.
A

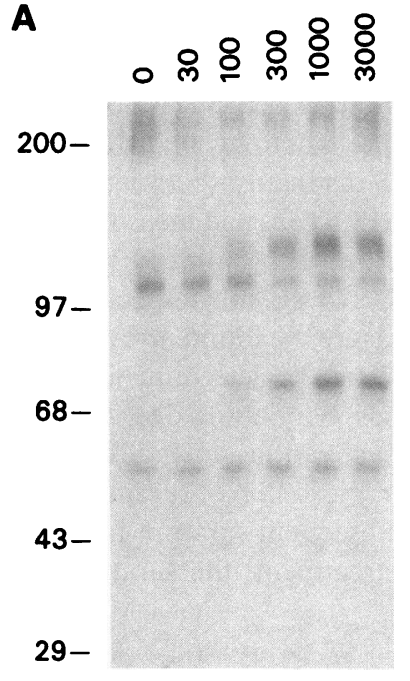

C
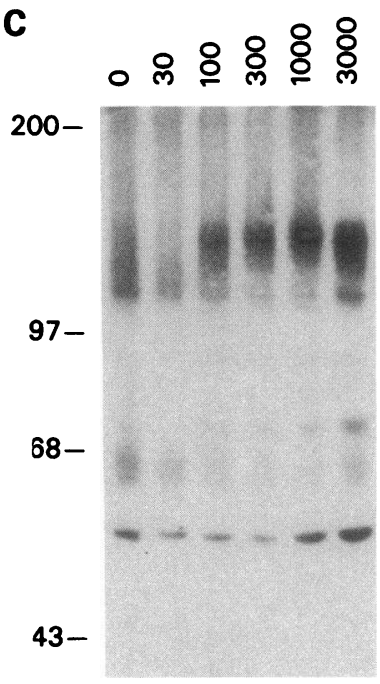

B

D
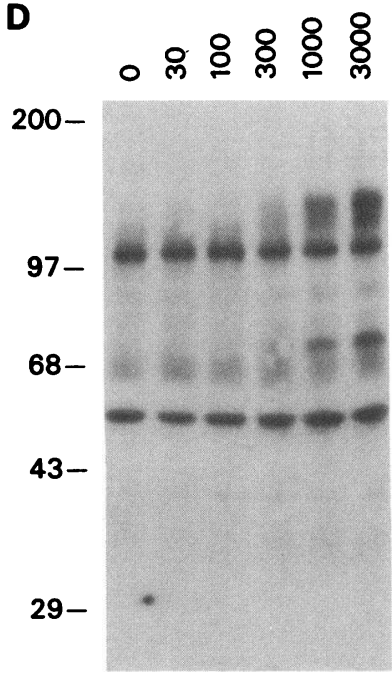

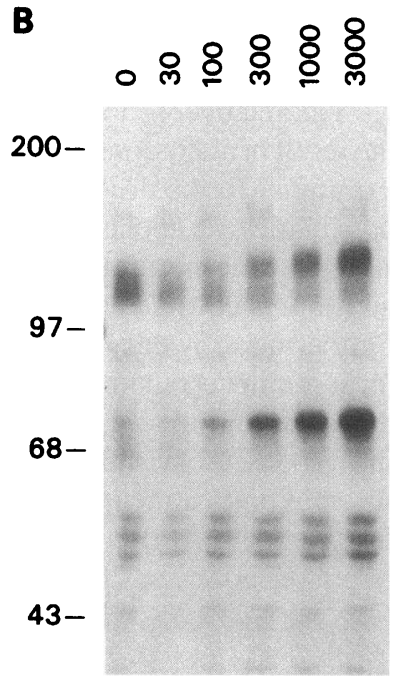

Figure 6. Dose-response curve for suramin-induced tyrosine phosphorylation in four human prostate cancer cell lines. Suramin at various concentrations $(0,30,100,300,1,000$, or $3,000 \mu \mathrm{g} / \mathrm{ml})$ was added to the media of $(A) \mathrm{PC} 3,(B) \mathrm{DU} 145,(C) \mathrm{PC} 3 \mathrm{M}$, or $(D)$ LNCaP. Cells were lysed $10 \mathrm{~min}$ after suramin addition and immunoblotted with the $4 \mathrm{G} 10$ monoclonal antibody after size fractionation by SDS-PAGE and transfer to nitrocellulose. The electrophoretic mobility of molecular size markers is shown in kilodaltons. 
Table I. Suramin Increases Tyrosine Phosphorylation of a 135and/or 75-kD Proteins in a Multiplicity of Cell Lines

\begin{tabular}{lcc}
\hline & $75 \mathrm{kD}$ & $135 \mathrm{kD}$ \\
\hline Prostate (PC3) & + & + \\
Prostate (PC3M) & + & + \\
Prostate (DU145) & + & + \\
Prostate (LNCaP) & + & + \\
Colon (HT 29) & + & + \\
Colon (630) & + & + \\
Colon (WiDR) & + & + \\
Colon (SW 620) & + & + \\
Colon (COLO 205) & + & + \\
Colon (716) & - & - \\
Gastric (TMK-1) & + & - \\
Gastric (A2521) & - & - \\
Gastric (NUGC4) & + & - \\
Gastric (MKN74) & + & - \\
Breast (ZR-75) & - & - \\
Breast (H5578) & - & - \\
Breast (T47D) & + & - \\
Breast (MDA-231) & + & - \\
Medulloblastoma (D283) & - \\
Neuroepithelioma (SKNMC) & - & - \\
Neuroepithelioma (TC32) & - & - \\
Neuroepithelioma (CHP100) & - & - \\
Lung (small cell) (H82) & - & - \\
Lung (small cell) (H417) & - & - \\
Lung (squamous) (H226) & - & - \\
Leukemia (HL60) & - & - \\
Leukemia (CEM) & - & - \\
Myeloma (H929) & - & - \\
Myeloma (U266) & - & - \\
Lymphoma (Wilson) & - & - \\
Lymphoma (Defauw) & - & - \\
Melanoma (RPMI 7951) & - & - \\
Melanoma (HS695T) & - & - \\
Cervical (HeLa) & - & - \\
Fibroblast (NIH 3T3) & - & - \\
\hline & - & - \\
\hline
\end{tabular}

Cells were lysed $10 \mathrm{~min}$ after $1,000 \mu \mathrm{g} / \mathrm{ml}$ suramin addition to the media. After size-fractionation (SDS-PAGE) and transfer to nitrocellulose, filters were blotted with an anti-phosphotyrosine antibody (4G10). Cell lines were categorized as having enhanced $(+)$ or not enhanced (-) bands at 75 or $135 \mathrm{kD}$.

Suramin is a highly sulfated polyanionic molecule at physiologic $\mathrm{pH}$. To determine whether or not other polyanionic compounds could induce acute alterations in tyrosine phosphorylation, heparin $(1-1,820 \mathrm{U} / \mathrm{ml})$, heparan sulfate $(10-50$ $\mu \mathrm{g} / \mathrm{ml}$ ), glycosaminoglycans purified from urine of suramintreated patients $(10-50 \mu \mathrm{g} / \mathrm{ml}$, see reference 26$)$ and pentosan polysulfate $(1-1,200 \mu \mathrm{g} / \mathrm{ml})$ were assayed in the 10 -min PC3 tyrosine phosphorylation assay. None of these compounds caused any alterations in tyrosine phosphorylation (data not shown). Protamine sulfate (3-100 $\mu \mathrm{g} / \mathrm{ml}$ ), a compound (like suramin) that reverses bFGF and PDGF action $(27,28)$, also had no effect on tyrosine phosphorylation in PC 3 cells. In addition, simultaneous additions of heparin and suramin did not demonstrate interactions between these two molecules (data not shown). These data demonstrate that the suramin-induced alterations in tyrosine phosphorylation are specific for suramin, and not simply dependent upon the presence of a highly charged polyanion.

Alterations in protein-tyrosine phosphorylation may be due to either activation of protein-tyrosine kinases or inhibition of protein-tyrosine phosphatases. To assess the possibility of kinase activation, we performed in vitro immune-complex kinase assays utilizing ${ }^{32} \mathrm{P}$-labeled ATP after anti-phosphotyrosine immunoprecipitations. Under such circumstances, autophosphorylating kinases, and in vitro kinase substrates that are immunoprecipitated by anti-phosphotyrosine antibodies will be detected as ${ }^{32} \mathrm{P}$-labeled proteins. After size-fractionation of the reaction products by SDS-PAGE (Fig. 8), a prominent $75-\mathrm{kD}$ band was detectable in the samples derived from suramin-treated PC 3 cells as well as the colon-derived cell lines (HT 29, SW 620, and COLO 205). Samples derived from the WIDR cell line (also colon-derived) had a less prominent, but detectable, band at $75 \mathrm{kD}$ as well. Of note, the $135-\mathrm{kD}$ band detected in immunoblots after suramin treatment was not detected in the immune-complex kinase assays, suggesting that the mechanism(s) of suramin-induced phosphorylation may differ for the 75- and $135-\mathrm{kD}$ proteins. Similar results were obtained in the PC3 and SW620 cells (other cells were not tested) when using antibody PY20 or $4 \mathrm{G} 10$ (not shown). These results indicate that anti-phosphotyrosine immunoprecipitates derived from suramin-treated PC 3 cells contain increased kinase activity relative to untreated PC 3 cells and suggest that suramin-induced increases in cellular phosphorylation may be the result of enhanced kinase activity.

To determine if the $75-\mathrm{kD}$ protein detected after suramin treatment is the same in prostate and colon cells, digestions with V8 protease were performed (using p75 labeled in immune-complex kinase reactions). Analysis of the ${ }^{32} \mathrm{P}$-labeled fragments by SDS-PAGE revealed peptides of identical size (Fig. 9), suggesting that suramin-induced tyrosine phosphorylation of $\mathrm{p} 75$ represents the same protein in cells derived from prostatic and colonic neoplasms. V8 proteolysis also confirms that the $75-\mathrm{kD}$ protein recognized by the PY20 monoclonal antibody is highly similar, if not identical, to that recognized by the 4G10 antibody (Fig. 9).

\section{Discussion}

The exact mechanism of suramin action has not been determined from these studies. The simplest hypothesis is that suramin directly alters the enzymatic activity of a protein-tyrosine kinase. However, our results do not rule out the possibility that a tyrosine phosphatase (s) is directly or indirectly involved, particularly in the phosphorylation changes detected in the 120 $\mathrm{kD}$ band. It is also possible that suramin acts via an "intermediate" compound which in turn modulates the activity of a protein-tyrosine kinase or phosphatase. Such an intermediate mechanism has recently been postulated for suramin-induced epidermal growth factor (EGF) receptor activation in the A431 cell line (29). In A431 cells, suramin treatment increases TGF$\alpha$ (as detected by radioimmunoassay) in the culture media in a time-dependent fashion and increases cellular tyrosine phosphorylation. In that study (29), neither TGF- $\alpha$ nor alterations in tyrosine phosphorylation were noted within the first several 


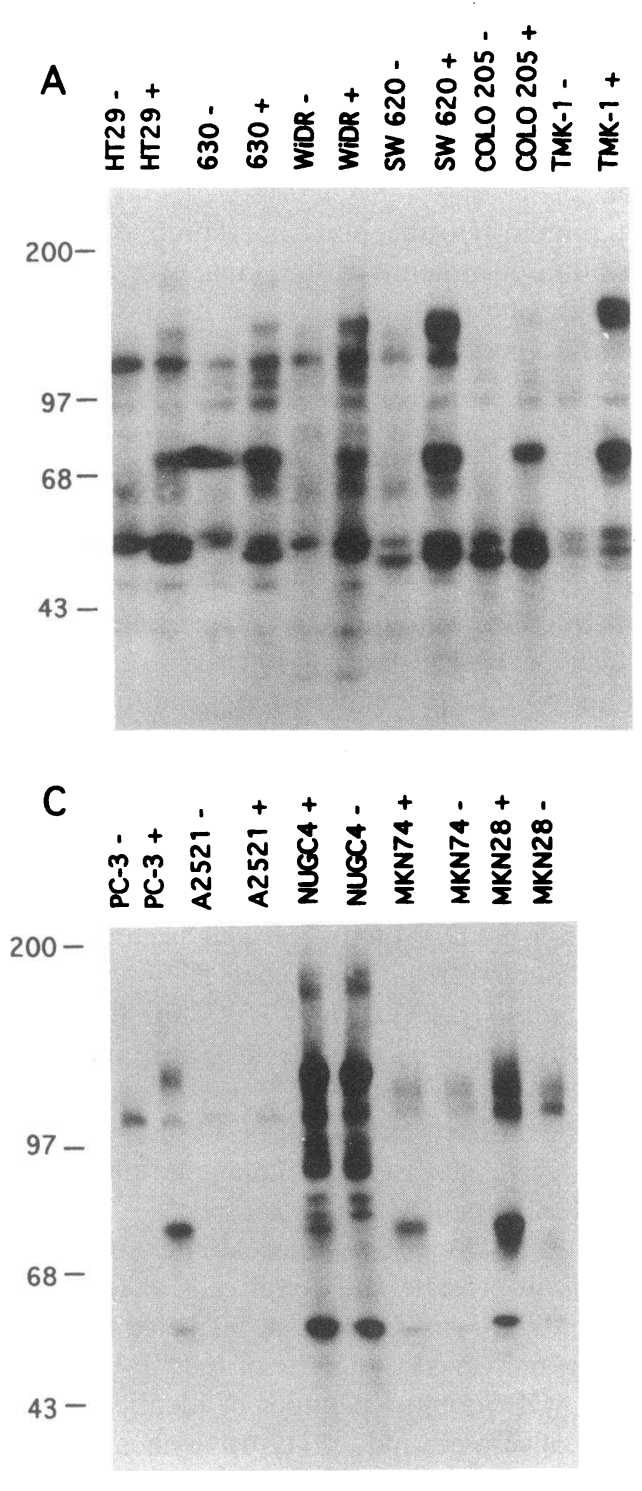

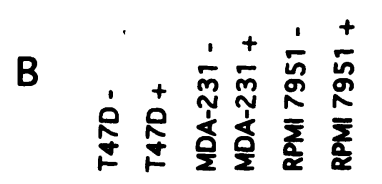
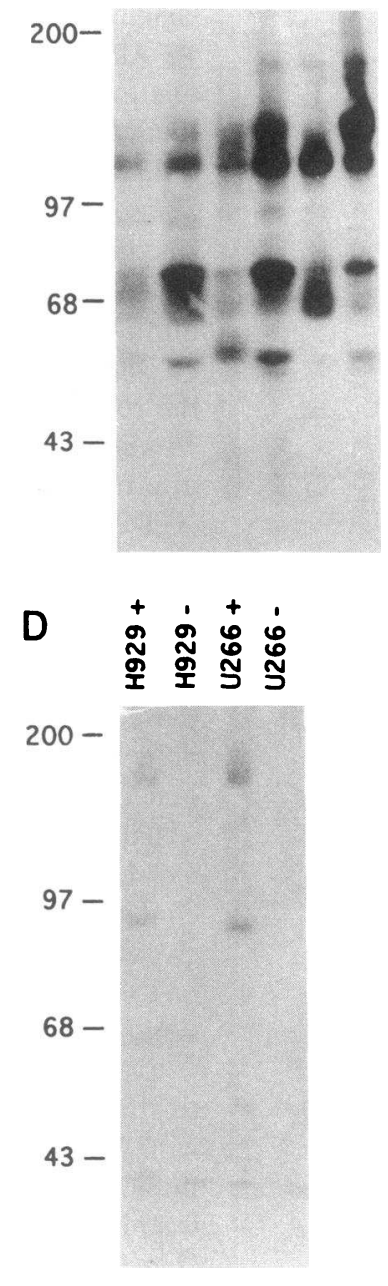

Figure 7. Suramin stimulates tyrosine phosphorylation in a series of human cancer cell lines. Suramin at a concentration of $0(-)$ or $1,000 \mu \mathrm{g} / \mathrm{ml}(+)$ was added to the media of various cell lines, and $10 \mathrm{~min}$ later cells were lysed and immunoblotted with the 4G10 antibody after SDS-PAGE and transfer to nitrocellulose. Panels $(A-D)$ Immunoblots containing lysates derived from different cell lines. The electrophoretic mobility of molecular size markers is shown in kilodaltons. hours after suramin treatment of A431 cells, however 20-72 h later there was a progressive increase in TGF- $\alpha$ within the conditioned medium and a progressive increase in cellular tyrosine phosphorylation with particularly prominent bands detected at $\sim 170 \mathrm{kD}$ (the size of the EGF receptor). In suramin-treated PC-3 cells, there are no differences in tyrosine phosphorylation after $72 \mathrm{~h}$ (Fig. $3 \mathrm{~B}$ ), no differences in TGF- $\alpha$ release into conditioned medium as detected by RIA (data not shown), and no tyrosine phosphorylation changes in proteins of $170 \mathrm{kD}$ (see Figures 2-7). Thus, though it is plausible that suramin-induced alterations in cellular tyrosine phosphorylation are secondary to release of an intermediate factor release, there is no evidence in PC3 cells for this factor being TGF- $\alpha$.

The suramin-induced effects on tyrosine phosphorylation are reminiscent of a ligand-receptor interaction in several respects: suramin induces the response within seconds of exposure to the cell, the response desensitizes after a relatively brief period of continuous exposure, and the desensitization is reversible after subsequent removal of the ligand. Thus, based upon these data, we postulate that suramin, or a suramin-induced intermediate, interacts with a receptor-like moiety at the cell surface.
Plausible candidates for the tyrosine-phosphorylated proteins detected in these studies include a variety of tyrosine kinases, and their substrates, with molecular masses of $\sim 75$ and $135 \mathrm{kD}$. Tyrosine kinases of $\sim 135 \mathrm{kD}$ include members of the FGF receptor family and the met proto-oncogene (hepatocyte growth factor receptor) (see references 17 and 30). Members of the $t r k$ family $(31,32)$, ret $(33)$, and the recently described 72-kD syk kinase (34) are also within the expected size ranges; however, these proteins are expressed in a tissue-specific manner that is not compatible with that found for the suramin-induced tyrosine phosphorylations. Potential tyrosine-phosphorylated "substrate" molecules include PLC- $\gamma(35,36)$, the ras GTPase-activating protein (GAP) $(37,38)$, and/or the 80 -, $120-, 125-$, and 130-kD tyrosine-phosphorylated proteins initially identified in fibroblasts expressing activated $s r c$ genes (23). In our preliminary experiments (utilizing antibodies to specific proteins in combination with anti-phosphotyrosine immunoblotting), we have failed to detect suramin-induced alterations in tyrosine phosphorylation for each of the "substrate" molecules mentioned above. Of interest, however, we did detect prominent expression and tyrosine phosphorylation of a p120 protein when utilizing the anti-p125 (2A7) antibody on 
PC3 cell lysates. In addition, we failed to detect alterations in tyrosine phosphorylation when utilizing antibodies directed against the product of the $f l g$ gene (an FGF receptor), the met proto-oncogene, or the $80-\mathrm{kD}$ subunit of the IL-6 receptor (data not shown). Thus the identities of the 75- and 135-kD suramin-induced bands are not known at this time and more experiments will be necessary to identify these molecules.

These studies clearly indicate that suramin effects are more complex than a simple abrogation of heparin-binding growth factors, a finding underscored by the recent demonstrations that suramin can block ATP binding to certain purinergic receptors (39) and can induce production of antiproliferative heparan sulfates (26). The rapid effects of suramin on tyrosine phosphorylation, at first glance, appear to be antithetical to suramin's role as an antitumor agent. However, these results suggest an alternative hypothesis for suramin's antitumor mechanism of action. Based upon our data, we hypothesize that a portion of the antitumor effect of suramin may be due to the activation, and subsequent down-regulation, of a signal
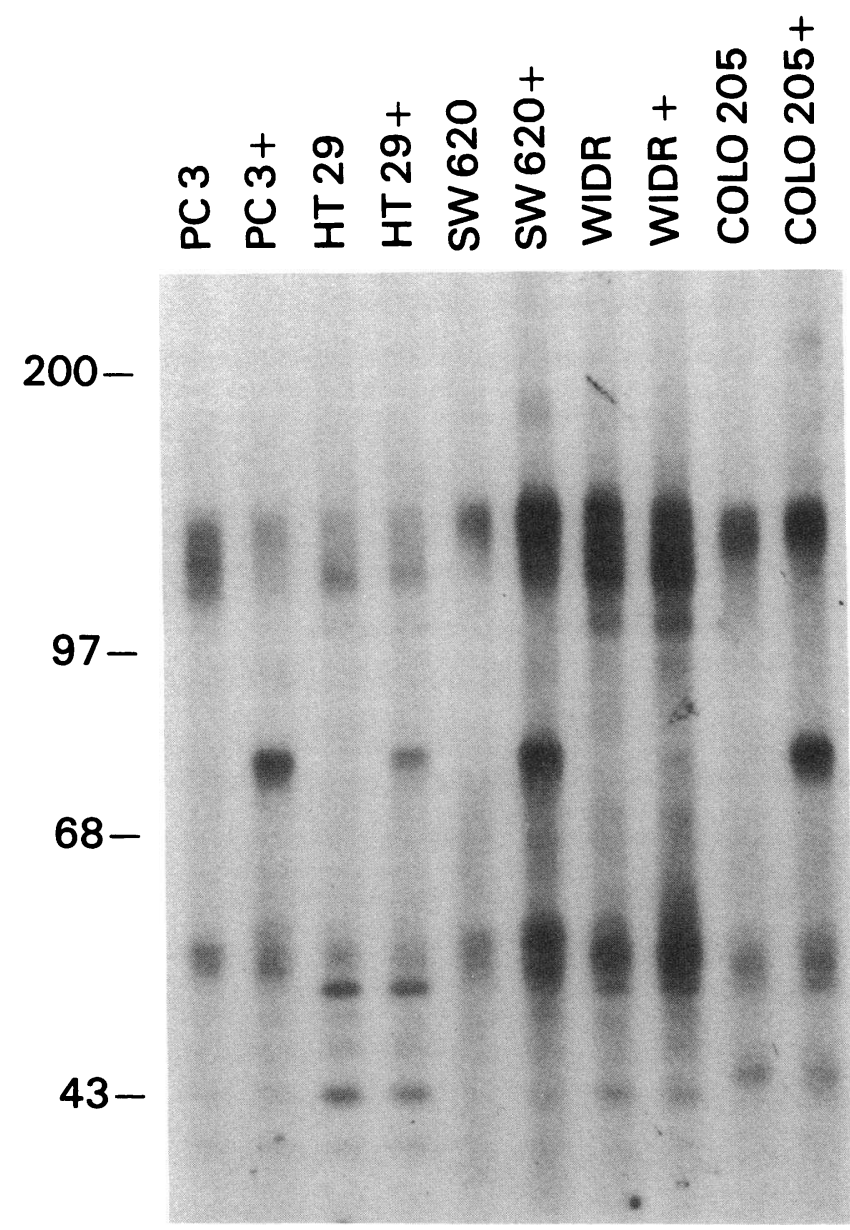

Figure 8. Cells treated with suramin have enhanced phosphorylation of a $75-\mathrm{kD}$ in vitro substrate as detected in anti-phosphotyrosine immune-complex kinase assays. Suramin at a concentration of 1,000 $\mu \mathrm{g} / \mathrm{ml}(+)$ was added to the cell media $10 \mathrm{~min}$ before cell lysis and proteins were immunoprecipitated with the monoclonal anti-phosphotyrosine antibody PY20. After performing immune-complex kinase assays with ${ }^{32} \mathrm{P}$-labeled ATP, the reactions products were size fractionated by SDS-PAGE and visualized by autoradiography. The electrophoretic mobility of molecular size markers is shown in kilodaltons.

\section{Cell Line:}

\section{PC-3 SW620}

Antibody:

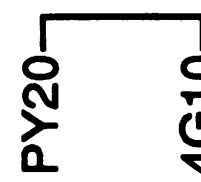

웅
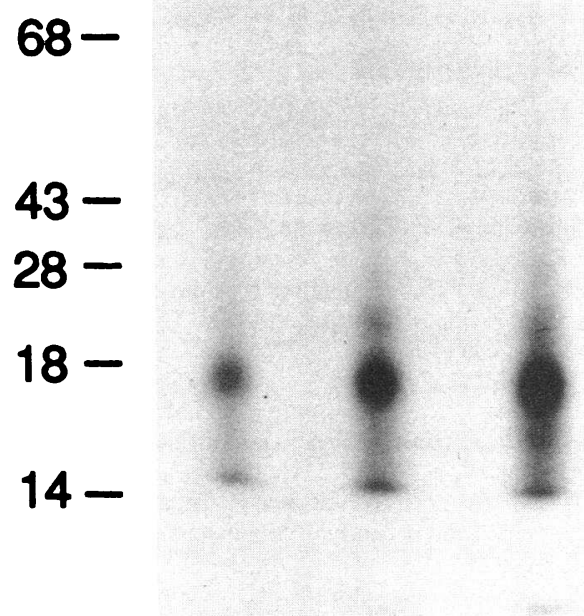

Figure 9. Singularity of the 75 protein detected in anti-phosphotyrosine immune-complex kinase assays. Immune-complex kinase assays were performed on PC3 or SW620 lysates according to the methods denoted in Fig. 8. After SDS-PAGE, the suramin-induced p75 band was excised and cleaved with V8 protease. Products of the proteolytic digestion were then size-fractionated by SDS-PAGE ( $14 \%$ gel) and visualized by autoradiography. The mobility of the molecular size markers is shown in kilodaltons.

transduction pathway essential for cancer cell growth. It is also plausible that alterations in signal transduction may play a role in suramin's antiparasitic action.

In summary, these studies clearly demonstrate an acute and marked alteration in the tyrosine phosphorylation of several cellular proteins in response to suramin treatment. In some cell lines, this response occurs at levels of the drug used in the clinical setting. To our knowledge, these studies represent the first demonstration of enhanced tyrosine phosphorylation by a nonpolypeptide pharmaceutical agent. Though our initial studies were restricted to prostate cancer cell lines, it is readily apparent that suramin can elicit similar changes in an assortment of cell lines derived from a variety of human tissues.

\section{Acknowledgments}

We would like to thank D. Hill, P. Gernt, M. Khan, and Dr. M. Cooper for their laboratory assistance; Dr. M. Ranson for providing glycosaminoglycans purified from the urine of suramin treated cancer patients; Dr. T. Parsons for providing antibodies to tyrosine-phosphorylated proteins; Dr. R. Nordan for providing IL-6 receptor antibodies; Dr. D. Bottaro for providing antibodies to the product of the met gene; and $\mathrm{J}$. Amber for editorial assistance.

\section{References}

1. Hawking, F. 1978. Suramin: with special reference to onchocerciasis. $A d v$. Pharmacol. Chemother. 15:289-322. 
2. Williams, L. T., P. M. Tremble, M. F. Lavin, and M. E. Sunday. 1984. Platelet-derived growth factor receptors form a high affinity state in membrane preparations. J. Biol. Chem. 259:5287-5294.

3. Hosang, M. 1985. Suramin binds to platelet-derived growth factor and inhibits its biological activity. J. Cell. Biochem. 29:265-273.

4. Betsholtz, C., A. Johnsson, C.-K. Heldin, and B. Westermark. 1986. Efficient reversion of simian sarcoma virus-transformation and inhibition of growth factor-induced mitogenesis by suramin. Proc. Natl. Acad. Sci. USA. 83:64406444.

5. Fleming, T. P., T. Matsui, C. J. Molloy, K. C. Robbins, and S. A. Aaronson. 1989. Autocrine mechanism for v-sis transformation requires cell surface localization of internally activated growth factor receptors. Proc. Natl. Acad. Sci. USA. 86:8063-8067.

6. Coffey, R. J., E. B. Leof, G. D. Shipley, and H. L. Moses. 1987. Suramin inhibition of growth factor receptor binding and mitogenicity in AKR-2B cells. $J$. Cell. Physiol. 132:143-148.

7. Yayon, A., and M. Klagsburn. 1990. Autocrine transformation by chimeric signal peptide-basic fibroblast growth factor: reversal by suramin. Proc. Natl. Acad. Sci. USA. 87:5346-5350.

8. Moscatelli, D., and N. Quarto. 1989. Transformation of NIH 3T3 cells with basic fibroblast growth factor or the $h s t / \mathrm{K}-f g f$ oncogene causes down regulation of the fibroblast growth factor receptor: reversal of morphologic transformation and restoration of receptor number by suramin. J. Cell Biol. 109:2519-2527.

9. Mills, G. B., N. Zhang, C. May, M. Hill, and A. Chung. 1990. Suramin prevents binding of interleukin- 2 to its cell surface receptor: a possible mechanism for immunosuppression. Cancer Res. 50:3036-3042.

10. Adams, J. C., R. A. Furlong, and F. M. Watt. 1991. Production of scatter factor by $n d k$, a strain of epithelial cells, and inhibition of scatter factor activity by suramin. J. Cell Sci. 98:385-394.

11. Stein, C. A., R. V. LaRocca, R. Thomas, N. McAtee, and C. E. Myers. 1989. Suramin, an anticancer drug with a unique mechanism of action. J. Clin. Oncol. 7:499-508.

12. LaRocca, R. V., R. Danesi, M. R. Cooper, C. Jamis-Dow, M. W. Ewing, S. Liu, W. M. Linehan, and C. E. Myers. 1991. Effect of suramin on human prostate cancer cells in vitro. $J$. Urol. $145: 123-129$.

13. Kim, J. H., E. R. Sherwood, D. M. Sutkowski, C. Lee, and J. M. Kozlowski. 1991. Inhibition of prostatic tumor cell proliferation by suramin: alteration in TGF alpha-mediated autocrine growth regulation and cell cycle distribution. J. Urol. 146:171-176.

14. Isaacs, J. T., R. A. Morton, P. Martikainen, and W. B. Isaacs. 1991. Growth factors affecting normal and malignant prostatic cells. In Growth Factors in Reproduction. D. W. Schomberg, editor. Springer-Verlag, Inc., New York. 167-184.

15. LaRocca, R. V., M. R. Cooper, M. Uhrich, R. Danesi, M. M. Walther, W. M. Linehan, and C. E. Myers. 1991. Use of suramin in treatment of prostatic carcinoma refractory to conventional hormonal manipulation. Urol. Clin. North Am. 18:123-129.

16. Myers, C. E., R. V. LaRocca, M. R. Cooper, R. Danesi, C. A. Jamis-Dow, and W. M. Linehan. 1991. Role of suramin in cancer biology and treatment. In Molecular Foundations of Oncology. S. Broder, editor. Williams \& Wilkins Co., Baltimore, MD. 419-431.

17. Aaronson, S. A. 1991. Growth factors and cancer. Science (Wash. DC). 254:1146-1153.

18. Park, J.-G., H. K. Oie, P. H. Sugarbaker, J. G. Henslee, T.-R. Chen, B. E. Johnson, and A. Gazdar. 1987. Characteristics of cell lines established from human colorectal carcinoma. Cancer Res. 47:6710-6718.

19. Carney, D. N., A. F. Gazdar, G. Bepler, J. G. Guccion, P. J. Marangos, T. W. Moody, M. H. Zweig, and J. D. Minna. 1985. Establishment and identification of small cell lung cancer cell lines having classic and variant features. Cancer Res. 45:2913-2923.
20. Brower, M., D. S. Carney, H. K. Oie, A. F. Gazdar, and J. D. Minna. 1986. Growth of cell lines and clinical specimens of human non-small cell lung cancer in a serum-free defined medium. Cancer Res. 46:798-806.

21. Laemmli, U. K. 1970. Cleavage of structural proteins during the assembly of the head of bacteriophage T4. Nature (Lond.). 227:680-685.

22. Sartor, O., J. H. Sameshima, and K. C. Robbins. 1991. Differential association of cellular proteins with family protein-tyrosine kinases. J. Biol. Chem. 266:6462-6466.

23. Kanner, S. B., A. B. Reynolds, R. R. Vines, and J. T. Parsons. 1990. Monoclonal antibodies to individual tyrosine-phosphorylated protein substrates of oncogene-encoded tyrosine kinases. Proc. Natl. Acad. Sci. USA. 87:33283332.

24. Supko, J. G., and L. Malspeis. 1990. A rapid isocratic HPLC assay of suramin (NSC 34936) in human plasma. J. Liq. Chromatogr. 13:727-741.

25. Sher, H. I., D. I. Jodrell, J. M. Iversen, T. Curley, W. Tong, and M. J. Egorin. 1992. Use of adaptive control with feedback to individualize suramin dosing. Cancer Res. 52:64-70.

26. Cooper, M. R., R. Danesi, R. LaRocca, M. Horne, and C. E. Myers. 1990. Suramin induces the production of antiproliferative heparan sulfate in patients with malignancies. Proc. Am. Assoc. Cancer Res. 31:1188a. (Abstr.)

27. Neufield, G., and D. Gospodarowicz. 1987. Protamine sulfate inhibits mitogenic activities of extracellular matrix and fibroblast growth factor, but potentiates that of epidermal growth factor. J. Cell. Physiol. 132:287-294.

28. Huang, J. S., J. Nishimura, S. S. Huang, and T. F. Duel. 1984. Protamine inhibits platelet derived growth factor receptor activity but not epidermal growth factor activity. J. Cell. Biochem. 26:205-220.

29. Cardinali, M., O. Sartor, and K. C. Robbins. 1992. Suramin, an experimental chemotherapeutic drug, activates the receptor for epidermal growth factor and promotes growth of certain malignant cells. J. Clin. Invest. 89:1242-1247.

30. Cooper, G. M. 1990. Oncogenes. Jones and Bartlett Publishers, Boston. $323 \mathrm{pp}$.

31. Martin-Zanca, D., M. Barbacid, and L. F. Parada. 1990. Expression of the $t r k$ proto-oncogene is restricted to the sensory cranial and spinal ganglia of neural crest origin in mouse development. Genes Dev. 4:683-694.

32. Klein, R., D. Martin-Zanca, M. Barbacid, and L. F. Parada. 1990. Expression of the tyrosine kinase receptor $\operatorname{trkB}$ is confined to murine embryonic and adult nervous system. Development. 109:845-850.

33. Takahashi, M., Y. Buma, T. Takashi, Y. Inaguma, H. Ikeda, and H. Hiroshi. 1988. Cloning and expression of the ret proto-oncogene encoding a tyrosine kinase with two potential transmembrane domains. Oncogene. 3:571578.

34. Taniguchi, T., T. Kobayashi, J. Kondo, K. Takahashi, H. Nakamura, J. Suzuki, K. Nagai, T. Yamada, S. Nakamura, and H. Yamamura. 1991. Molecular cloning of a porcine gene $s y k$ that encodes a $72-\mathrm{kDa}$ protein-tyrosine kinase showing high susceptibility to proteolysis. J. Biol. Chem. 266:15790-15796.

35. Kumjian, D. A., M. I. Wahl, S. G. Rhee, and T. O. Daniel. 1989. Plateletderived growth factor (PDGF) binding promotes physical association of PDGF receptor with phospholipase C. Proc. Natl. Acad. Sci. USA. 86:8232-8239.

36. Meisenhelder, J., P.-G. Suh, S. G. Rhee, and T. Hunter. 1989. Phospholipase C-gamma is a substrate for the PDGF and EGF receptor protein-tyrosine kinases in vivo and in vitro. Cell. 57:1109-1122.

37. Kaplan, D. R., D. K. Morrison, G. Wong, F. McCormick, and L. T. Williams. 1990. PDGF $\beta$-receptor stimulates tyrosine phosphorylation of GAP and association of GAP with a signalling complex. Cell. 61:125-133.

38. Molloy, C., D. P. Bottaro, T. P. Fleming, M. S. Marshall, J. B. Gibbs, and S. A. Aaronson. 1989. PDGF induction of tyrosine phosphorylation of GTPase activating protein. Nature (Lond.). 342:711-714.

39. Hoyle, C. H., G. E. Knight, and G. Burnstock. 1990. Suramin antagonizes responses to P2-purinoreceptor agonists and purinergic nerve stimulation in the guinea-pig urinary bladder and taenia coli. Br. J. Pharmacol. 99:617-621. 